Digitalizacja archiwalnych numerów czasopisma naukowego Analecta Cracoviensia 1-24 (1969-1992) i ich publikacja w otwartym dostępie - zadanie finansowane w ramach umowy 672/P-DUN/2017 ze środków Ministra Nauki i Szkolnictwa Wyższego przeznaczonych na działalność upowszechniającą naukę

\title{
WLADYSŁAWA WITWICKIEGO KONCEPCJA RELACJI MIĘDZY NAUKĄ A WIARĄ
}

W historii nauki polskiej Władysław Witwicki $(1878$ - 1948) znany jest przede wszystkim jako psycholog. Znawcy twierdzą, że do połowy XX w. „był bezspornie najwybitniejszym spośród polskich psychologów"1. Długie lata pracy pedagogicznej na tym polu, a także dwutomowy uniwersytecki podręcznik Psychologii są tego jasnym dowodem ${ }^{2}$. W. Witwicki koncentrował się zwłaszcza na psychologii religii, która „była główną dziedziną jego badań naukowych"3. Najważniejsze prace z tego okresu to: Wiara oświeconych, Dobra nowina wedtug Mateusza i Marka, rozdział o religijności we wspomnianej już Psychologii, a także recenzje książek ks. Jana Nuckowskiego (1903, 1904), ks. Idziego Radziszewskiego (1911), pracy zbiorowej pt. Darwinizm a wiedza wspótczesna (1910), dwóch religioznawczych prac Ryszarda Gansińca $(1919,1920)$ oraz referat wygłoszony na Pierwszym Zjeździe Filozofów Polskich w $1923 \mathrm{r}^{4}{ }^{4}$. Stan badań nad pracami o tematyce religijnej W. Witwickiego jest skromny. Poza kilkoma recenzjami, dwoma rozdziałami książki Jana Szmyda (Osobowość a religia. Z psychologii religii w Polsce, Warszawa 1979, s. $227-280,367-375)$ i kilkunastoma artykułami ${ }^{5}$ nic więcej nie zostało opublikowane.

Jedna z naczelnych cech pracy naukowej W. Witwickiego to przede wszystkim dążność do doskonałej ścisłości, jasności i zrozumienia otaczającej go rzeczywistości we wszystkich jej przejawach. Takie podejście do nauki odziedziczył po swoim profesorze K. Twardowskim, a ten z kolei po E. Kancie. Trzeba jednak zauważyć, że jakkolwiek K. Twardowski poszedł dalej niż Kant (cho-

${ }^{1}$ A. Nowi cki, Witwicki, Warszawa 1982, s. 61.

2 J. B u d ki ewi cz, Wtadystaw Witwicki jako psycholog, „Ruch Filozoficzny” 33:1975 nr 1 s. $1-9$

A. Nowi cki, Inedita Wtadystawa Witwickiego (1878-1948). Ankieta w sprawie utraty wiary religijnej (rękopis), „Euhemer - Przegląd Religioznawczy” 23: $1980 \mathrm{nr} 3$ (117) s. 103; por. T. R ze pa, Autoprezentacja Wtadystawa Witwickiego w listach do syna, „Studia Philosophiae Christiane" $23: 1987 \mathrm{nr} 2$ s. 131.

${ }^{4}$ A. Nowicki, Witwicki..., s. $79-90$.

${ }^{5}$ Kilka z nich zamieszcza „Euhemer - Przegląd Religioznawczy” 33 : 1989 nr 1 (151). W numerze tym jest również bibliografia ważniejszych prac W. Witwickiego oraz prac jego dotyczących w opracowaniu A. Nowickiego (s. 193-220). 
ciaż to twierdzenie uważają niektórzy autorzy za dyskusyjne), to W. Witwicki formułował bardziej radykalnie niż czynił to $\mathrm{K}$. Twardowski postulaty epistemologiczne i metodyczne, dotyczące badań naukowych. Filozofia naukowa według W. Witwickiego opierała się na danych wynikających ze spostrzeżeń zmysłowych i na poznaniu rozumowym, które prowadzi do nieodpartych wniosków. W takim ujęciu filozofii umieścił swoją koncepcję psychologii, która zajmuje się badaniem przedmiotów świata realnego, danego nam w doświadczeniu wewnętrznym i zewnętrznym (empiryzm) ${ }^{6}$.

Wychodząc z tego typu filozofii i psychologii, Witwicki podjął zagadnienie wyjaśnienia wiary religijnej i możliwości potwierdzenia jej w badaniach eksperymentalnych. Obydwa zagadnienia sprowadził do analizy relacji między nauką a wiarą religijną. Problem ten jest nadal ważny, tak na płaszczyźnie teoretycznej, jak i praktycznej. Wskazuje na to między innymi wiele najnowszych publikacji ${ }^{7}$.

Zdaniem W. Witwickiego istnieje naprawdę tylko to, co jest poznawane dzięki zmysłom człowieka. Teza ta w okresie jej sformułowania mogła ucho-

${ }^{6}$ J. Woleńs ki, Filozoficzna Szkota Lwowsko-Warszawska, Warszawa 1985, s. 36 - 42; B.A.G. Full e r, Historia filozofii. T. 2: Filozofia nowożytna, przeł. Cz. Zn a mi e row s k i, Warszawa 1967, s. 607 - 613; por. A. D on d y n e, Un discours philosophique sur Dieu est-il encore possible, [w:] Miscellanea, Albert Dondeyne, Leuven 1974, s. 426-428; S. W y lęż e k, Znaczenie i pewność zdań teologii w filozofii Alfreda Julesa Ayera, Kraków 1976 (maszynopis pracy licencjackiej w Archiwum Papieskiej Akademii Teologicznej w Krakowie), s. 12, 16, 17 - 23, 26 - 29; T. Rze pa, Wspomnienia o Wtadystawie Witwickim, „Przegląd Psychologiczny” 31 : $1988 \mathrm{nr} 3$ s. 756 -758; A. Nowi cki, Filozofia Wtadystawa Witwickiego, „Euhemer - Przegląd Religioznawczy” $33: 1989 \mathrm{nr} 1(151)$ s. $59-64$.

${ }^{7}$ Por.: J. G. B a r bou r, Mity, modele, paradygmaty. Studium porównawcze nauk przyrodniczych i religii, Kraków 1984; M. B u dza now s k a, Refleksje nad „,Wiarq oświeconych”, „Atenemum Kapłańskie" $52: 1960$ t. 60 z. 1 s. 138 - 153; A. D on d y y e, Une discours philosophique sur Dieu est-il encore possible?, [w:] Miscellanea. Albert Dondeyne, Louvain 1974, s. 418 - 448; Filozofować w kontekście nauki, red. M. Helle r, A. Mi ch alik, J. Ż y ci ńs ki, Kraków 1987; M. Gogacz, Wiara i nauka, „Collectanea Theologica” 39:1969 z. 3 s. 83-96; J. Hacking, The Participant Irrealist at Large in the Laboratory, „British Journal for the Philosophy of Science” 39 : 1988 z. 3 s. 227 - 294; M. J a w or s ki, Religijne poznanie Boga wedtug Romana Guardiniego, Warszawa 1967; tenże, Przedfilozoficzne i filozoficzne poznanie Boga, [w:] Studia z filozofii Boga, red. B. Bejze, Warszawa 1968, s. 333 - 346; tenże, Bóg filozofów a Bóg wierzacych, [w:] O Bogu i o cztowieku. Problemy filozoficzne i teologiczne, red. B. B e j z e, t. 2, Warszawa 1969, s. 97 106; tenże, Inspiracje soborowe w filozofii (rozum i wiara), [w:] Myśl posoborowa w Polsce, red. I. Myśk ów, Warszawa 1970, s. 28 - 48; tenże, Doświadczenie religijne. Próba filozoficznej interpretacji, „Zeszyty Naukowe KUL” 16:1973 nr 3/4 s. 19 - 28; tenże, Doświadczenie religijne w ujęciu fenomenologicznym, [w:] W kierunku religijności, red. B. B e jze, Warszawa 1983, s. 59 - 74; W. Kostecki, Wiara i ludzie oświeceni, „Znak” 12 : 1960 s. $688-701$; M. K rą pi ec, Religia a nauka, „Znak” 19 : 1967 nr 157 s. $861-887$; J. La d riè re, L'articulation du sens. Discours scientifiques et parole de la foi, Paris 1970 - 1984; tenże, Nauka - filozofia - wiara, „Znak” 28 : 1976 nr 260 s. 256 - 278; tenże, Nauka, świat $i$ wiara, tł. A. P a y ge r t, Warszawa 1978; J. M a k selon, Relacje między psychologiq a religia, „Analecta Cracoviensia” 20 : 1988 s. 41 - 49; E. Nieznański, Logika przekonań a wiara oświeconych, „Studia Philosophiae Christianae” 21 : $1985 \mathrm{nr} 1$ s. 157 - 162; T. Rze pa, Problemy religii w kontekście uwag na temat wychowania w listach Wtadystawa Witwickiego do syna Tadeusza z lat 1918 - 1945, „Euhemer” 33 : $1989 \mathrm{nr}$ 1 (151) s. 45 - 58; J. T i s ch ne r, Myślenie religijne, „Znak” $32: 1980 \mathrm{nr} 317 \mathrm{s.} 1375-1392 ; \mathrm{A}$. N. Wh i teh ead, Religia a nauka, tł. M. Helle r, "Znak" 32 : $1980 \mathrm{nr} 308$ s. $228-238$; Z. J. Z d ybi cka, Religia i.religioznawstwo, Lublin 1988; J. Ży ci ńs ki, Metodologiczne aspekty konfliktu religii z naukq, [w:] Nauka - religia -dzieje. Seminarium w Castel Gandolfo, 16-19 sierpnia 1980 r., Roma 1981, s. 75 - 90; tenże, Język i metoda, Kraków 1983; tenże, Teizm i filozofia analityczna, t. 1 -2, Kraków 1985 - 1988, tenże, W kręgu nauki i wiary, Kalwaria 1989. 
dzić za zbliżoną treściowo do koncepcji sensowności przyjętej przez pozytywizm logiczny. W duchu bliskim sensualizmowi uznawano w niej, iż dzięki danym zmysłowym w podmiocie poznającym powstaje nowy element psychiczny, a mianowicie przekonanie, że nie ma się do czynienia z jakimiś zwidami czy majakami, ale zbiorem danych, którym odpowiadają realne obiekty ${ }^{8}$. Taki sposób podejścia naukowego (filozoficznego i psychologicznego) zapewniał mu szereg osiągnięć, ale również był powodem wielu nieporozumień, kontrowersyjnych ujęć, zwłaszcza w dziedzinie badań dotyczących religijności.

Analizując tę ważną dziedzinę życia człowieka i związane z nią przeżycia psychiczne, kładł Witwicki główny nacisk na jej aspekt poznawczy i etyczny. Usiłował przedstawić, a nawet rozwiązać problem relacji pomiędzy wiarą a nauką na płaszczyźnie, zarówno sumienia, jak i poznania. Pisał, iż jego praca „nie zajmuje się wcale przedmiotami wiary, tym w co ludzie wierzą, nie wypowiada żadnych twierdzeń o przedmiotach wiary, których spostrzegać nie można, poświęcona jest wyłącznie tylko badaniom aktów wierzenia i stosunku ludzi wierzących do treści wiary" 9 .

W. Witwicki zamierzał więc w swej pracy podać filozoficzno-psychologiczne wyjaśnienie, w jaki sposób człowiek wykształcony w dziedzinach nauk świeckich potrafi pogodzić w sobie i zaakceptować, względnie nie zaakceptować, te dwie - jak sądził — sprzeczne i wykluczające się wzajemnie rzeczywistości. Więcej - w jaki sposób potrafi zaakceptować dziedzinę wiary najeżoną sprzecznościami, tajemnicami i nieludzkimi, wręcz odrażającymi faktami, budzącymi sprzeciw rozumu, naturalnej etyki i estetyki, których nie brakuje w danych objawienia Starego i Nowego Testamentu. Posługując się metodą ankietową, starał się w swych badaniach dotrzeć do wnętrza badanych osób, by otrzymany w ten sposób materiał poddać następnie analizie i przedstawić go na tle ówczesnej psychologii religii. Poddawał również wnikliwej analizie teksty teologiczne, które starają się fakt wiary precyzyjnie ująć i znajduje w nich ten sam pierwiastek, jaki jego analiza psychologiczna znajdowała u badanych osób.

Sam autor wspomnianej książki w liście (nigdzie dotychczas nie opublikowanym) z 3 września 1938 roku do prof. Izydory Dąmbskiej, proponując tekst notatki do prasy o Wierze oświeconych, napisał między innymi:

Praca poświęcona psychologicznemu pogłębieniu faktu wiary religijnej osób oświeconych, a tym samym staremu problemowi stosunku wiary do rozumu [...] W przeżyciu religijnym wielu osób badanych analiza naukowa potrafiła wykryć elementy znane z przeżyć estetycznych, które godzą się psychologicznie z przekonaniami (przy zachowaniu logicznej i psychologicznej zasady sprzeczności?) [...] Praca wolna od wszelkiej tendencji wyznaniowej - poświęcona wyłącznie obiektywnemu badaniu faktu psychologicznego, zasługuje na uwagę wszystkich, którzy bądź to sami myślą, że przeżywają kolizję bez wyjścia między [swoim] rozumem a wiarą, oraz tych, którzy

${ }^{8}$ W. Wit wicki, Psychologia, t. 1, Warszawa 1962, s. 226.

${ }^{9}$ Tenże, Wiara oświeconych..., Warszawa 1959, s. 23. 
się zajmują tą nad wyraz interesującą i trudną dziedziną życia wewnętrznego albo pragną nią kierować u drugich. Załączone protokoły badań — to jakby okienka otwarte, przez które widzi się żywą pracę żywej duszy ludzkiej na gorąco - in statu nascendi chwyta się budzące się kolizje i sposoby, z pomocą których ludzie szukają z nich wyjścia. Autor tę kolizję rozwiązuje, zwracając uwagę na istotną różnicę psychologiczną, jaka dzieli wiedzę i wiarę w myśl nauki samego Kościoła katolickiego, zawartej w jego autentycznych tekstach ${ }^{10}$.

Celem niniejszego artykułu jest przedstawienie przyjętych założeń i kategorii naukowo-badawczych W. Witwickiego, jego poglądów na wiarę, a także wykazanie, że wnioski tego autora, dotyczące stosunku wiary do rozumu u człowieka oświeconego, są uwarunkowane jego filozoficzną koncepcją poznania i nie rozwiązują problemu w sposób zadowalający.

\section{PODSTAWOWE ZAŁOŻENIA EPISTEMOLOGICZNE DOTYCZĄCE NAUKI I PRAWDY}

Wyrażając swe poglądy na istotę poznania naukowego $\mathrm{W}$. Witwicki powtarza scjentystyczne ujęcia swej epoki, w których usiłowano rezerwować dla nauki wyłącznie funkcje poznawcze. Naukę stwarza rozum - pisze on - pod ustawiczną kontrolą faktów i ciągłej zależności od nich ${ }^{11}$. Studium naukowe prowadzi do prawdy, a do odkrycia tej prawdy „,powołany i uzbrojony jest tylko badacz"12. Jemu - uczonemu, badaczowi - nie wolno zabarwiać subiektywnie wyników swej pracy, nie wolno mu przekształcać tego, co mu powie racjonalna analiza, według osobistych upodobań „,czy dla zaokrąglenia całości, dla celów estetycznych"13. Badacz ,jest kochankiem wiedzy: szuka prawdy i odsłania to, co rzeczywiste" 14 , pracuje intelektem i dla intelektu tworzy, z chaotycznego, surowego materiału, którego dostarcza mu doświadczenie, tworzy całość zorganizowaną. Mieszkają w nim niepokoje wewnętrzne, które go pędzą do pracy i do utrwalania wyników swych prac, aby je przekazać odbiorcom. Badacz chce poznać i przedstawić to, co jest, i mówić tak, jak sprawa wygląda w rzeczywistości. Przy pomocy intelektu i doświadczenia, dochodząc do prawdy, woli jej najmniejszą odrobinę, czyli odrobinę zgodności poznania z rzeczywistością, „niż całe choćby najbardziej urocze światy rojeń, baśni, złud, przesądów, pozbawionych legitymacji naukowej. W zakresie nauk indukcyjnych legitymacji tej dostarcza sądom poszczególnym doświadczenie, w zakresie de-

${ }^{10} \mathrm{Z}$ listu W. Witwickiego do I. Dąmbskiej z dnia 3 IX 1938 r. (przekazanego ks. Janowi Bednarczykowi przez prof. Izydorę Dąmbską dnia 28 kwietnia 1983 r.).

${ }_{11}$ W. Witwicki, Sztuka a nauka, „Ateneum Polskie” 1 : 1908 nr 3 s. 284.

12 Tamże, s. 287.

13 Tamże, s. $282-283$.

${ }^{14}$ Tenże, O stosunku nauki do sztuki, „Nauka Polska” 3 : 1920, s. 53; J. J e żew s k a, Stowo od wydawcy, [w:] W. Wit wick i, Platona Eutyfron, Obrona Sokratesa, Kriton, Warszawa 1958, s. $6-8$. 
dukcji oczywistość bezpośrednia lub związek z zasadami pierwszymi, w każdym: jednoznaczność terminów i bezsprzeczność twierdzeń"15.

Wyrażając takie właśnie przekonania i absolutyzując wartość poznania naukowego, W. Witwicki twierdził m. in., że „najistotniejsze znaczenie dla człowieka ma poznanie prawdy, pojmowanej jako wartość sama w sobie"16. Sam wyznał wiarę w to, ,że prawda w każdej sprawie na końcu na dobre wyjdzie, choćby na razie była przykra, bolesna, ciężka i mało do prawdy podobna"17. Podobnie jak pozytywiści jego epoki, był zwolennikiem ciągłej weryfikacji naukowej odkrytych i podanych twierdzeń dotychczasowej wiedzy ${ }^{18}$. Gwarancją prawdy nie może być ani umiejętność przekonania o niej drugich, ani też powszechna na nią zgoda ${ }^{19}$. Ponieważ jest możliwe zdobycie pewnej trwałej wiedzy o świecie, a także osiągnięcie prawdy obiektywnej o rzeczywistości, należy prowadzić badania, $m$. in. opierając się na niezawodnym „narzędziu”, jakim jest ontologiczna zasada sprzeczności, będąca „fundamentem naszego poznania”20. W tym świetle zwrot: „prawda jest jedna”, nic innego nie znaczy, jak tylko to, że „rzeczy i zdarzenia, ujmowane uważnie z pomocą jasnych pojęć, okazują się wolne od sprzeczności wewnętrznych"21.

Przyjmując dwa typy myślenia: dyskursywny i intuitywny, dwa rodzaje poznania: intelektualne i uczuciowe ${ }^{22}$, pierwszeństwo przypisuje pierwszym w badaniach naukowych oraz przyznaje najważniejsze znaczenie spostrzeżeniom, dzięki którym powstają przekonania ${ }^{23}$. Przez spostrzeżenia rozumie „fakt psychiczny nie prosty, tylko złożony, w którym wyróżnić musimy przynajmniej trzy elementy: jedno przedstawienie i najmniej dwa sądy"24. Przedstawieniem nazywa to, co się dzisiaj nazywać zwykło wyobrażeniem. To przedstawienie nie może być ani prawdziwe ani fałszywe. Można sobie przedstawić np. „,zagon kwitnących lilii białych lub rzadkich storczyków i to przedstawienie nie jest wcale fałszywe, chociaż taki zagon nie istnieje"15. Wspomniane dwa sądy, to sąd realizujący i klasyfikujący ${ }^{26}$.

Jeżeli chodzi o zadania nauki, to ma ona „ustalać byt, opisywać i podawać prawa tego, co istnieje i co się zawsze powtarzać musi"27. Podobne sformuło-

15 Tamże, s. 55 nn.

${ }^{16}$ R. Ja dcza k, Wtadystaw Witwicki. O prawdzie, rodzajach poznania ifunkcjach nauki, [w:] Księga pamiątkowa ku czci Prof. Tadeusza Czeżowskiego, Toruń 1980, s. 1451.

17 W. Wit wi k i, Platona Eutyfron, Obrona Sokratesa, Kriton, Warszawa 1958, s. 7.

18 Tenże, Analiza psychologiczna objawów woli, Lwów 1904, s. 18; por. A. Now i cki, Listy

W. Witwickiego z lat 1939-1947 (inedita), „Euhemer-Przegląd Religioznawczy” $1978 \mathrm{nr} 2$ s. 17.

${ }_{19}$ W. Witwicki, Komentarz do: Pl a to n, Gorgiasz, Warszawa 1958, s. 190.

20 Tenże, Wiara oświeconych..., s. 62.

21 Tenże, Rozmowa o jedności prawdy i dobra, Lwów 1936, s. 22; por. tegoż objaśnienia w: Plat on, Teajtet, Warszawa 1936, s. 203 - 209.

22 Tenże, William James jako psycholog, „Przegląd Filozoficzny” 16 : 1913 s. 22 - 26; tenże, Rozmowa..., s. 18.

${ }^{23}$ Tenże, Rozmowa..., s. 21 n.; tenże, Wiara oświeconych..., s. $58-59$.

24 Tenże, Psychologia, t. 1..., s. 227.

25 Tenże, Wiara oświeconych..., s. 25.

26 Tenże, Psychologia, t. $1 \ldots$, s. 227.

27 Tenże, List 0 estetyce, „Przegląd Filozoficzny” 45 : 1949 s. 24 
wania wikłają się w niekonsekwencji zarówno przy próbach sprecyzowania terminu „byt”, jak i przy pytaniu o warunki powtarzalności zdarzeń. Współczesna kosmologia np. bada wszechświat, w którym poszczególne zdarzenia są niepowtarzalne. Nie traci ona przez to bynajmniej naukowego charakteru, co w czasach W. Witwickiego dostrzegał już m. in. młody Popper ${ }^{28}$.

W wizji promowanej przez W. Witwickiego poznawczym „odpowiednikiem tego wszystkiego, co istnieje, jest w szerszym poznaniu prawda" ${ }^{29}$. Sfera doznań leżąca poza przedmiotem dociekań naukowych i nie wymagająca ścisłych, krytycznych metod poznania — to świat poezji, religii, sztuki. Do tego świata mogą się odnosić nasze złudzenia, marzenia, sny ${ }^{30}$. Decyzja taka ma charakter deklaracji ontologicznej, w której Autor arbitralnie określa granice rzeczywistości, zacierając specyfikę dziedzin tak odległych jak poezja i religia. Decyzji tej trudno byłoby Witwickiemu bronić przy pomocy racjonalnych argumentów ${ }^{31}$

Badania naukowe, myślenie naukowe, wchodzą w zakres całości życia psychicznego, życia duchowego, które łącznie z procesami myślenia, z procesami poznawczymi „przeżywamy (zdawałoby się okresowo) w dwóch różnych postaciach typowych: snu i jawy"32. „Zdaniem Witwickiego nauka jest wytworem myślenia w typie jawy, a przeciwstawia się mu myślenie w typie snu, w którym obraz świata jest wolny, kapryśny, nie wykluczający sprzeczności i niekoherencji" ${ }^{33}$.

Z powyższych wypowiedzi na temat nauki i prawdy można wysnuć poprawny — wydaje się — wniosek, że drogą do prawdy są tylko badania naukowe, które, opierając się na danych spostrzeżeniowych i rozumowych, ograniczają się do świata naturalnego. Świat teligijny leży poza danymi nauki i jest fikcją. Wniosek ten wydaje się uzasadniać następująca wypowiedź:

„W wierzeniach religijnych mamy również niewyczerpaną kopalnię zbitek o cechach wyłączających się tak jaskrawo, jak początek i brak początku w czasie, wszechmoc i ograniczona moc ludzka, śmiertelność i nieśmiertelność, wszechwiedza i niewiedza w jednej i tej samej osobie, mamy męki niewinne w imię sprawiedliwości, a nawet miłości, mamy odpowiedzialność bez winy, a obok niemożliwość logicznych i paradoksów moralnych nieskończony szereg niemożliwości przyrodniczych w formie cudów i legend. Cały ten świat, tak żywy w okresie dzieciństwa i naturalny w umyśle ludzi pierwotnych, zgodny z całością dziecięcego, bajkowego poglądu na rzeczy — utrzymuje się w bardzo wielu umysłach dojrzałych tak samo, jak się utrzymuje zdolność do marzeń sennych u tych, którzy w dzień doskonale potrafią czuwać ${ }^{34}$. 184.

${ }^{28}$ W. H. Newton-Smith, The Rationality of Science, Routledge and Kegan Paul 1981, s.

${ }^{29}$ W. Wit wicki, Wiliam James jako psycholog..., s. 33.

${ }^{30}$ Tamże, s. 26.

${ }^{31}$ T. Set t le, Is Scientific Knowledge Rationally Justified?, [w:] Basic Issues in the Philosophy of Science, New York 1976, s. 31.

${ }_{32}$ W. Wi t wi cki, Z filozofii nauki, „Przegląd Warszawski” 3 : 1923 nr 24 s. 290.

${ }^{33} \mathrm{I}$. D ą m bska, Z refleksji Wtadystawa Witwickiego nad nauka $i$ jej stosunkiem do innych dziedzin życia, „Ruch Filozoficzny” 33 : $1975 \mathrm{nr} 1 \mathrm{~s} .11$.

${ }^{34}$ W. Witwicki, Z filozofii nauki..., s. 295. 
Wypowiedzi swoje na temat nauki Autor przedstawia w swoich publikacjach, np. Sztuka a nauka ${ }^{35}$, O stosunku nauki do sztuki ${ }^{36}$; najpełniejsze ujęcie tego problemu podaje chyba w swojej Psychologii. Pisze, iż „nauka, w przeciwstawieniu do owej niby-wiedzy pierwotnej, stara się być jasna i ścisła. Jasna — to znaczy, że unika słów, które i tak rozumieć można, i inaczej; prawdziwe lub fałszywe może być tylko twierdzenie jednoznaczne. Śisła-znaczy, że posługuje się stale tym samym słowem w tym samym znaczeniu i nie uznaje za prawdziwe twierdzeń, które bądź to nie są bezpośrednio oczywiste same przez się, bądź też nie wynikają koniecznie i nieuchronnie $\mathrm{z}$ innych, oczywistych. Nauka zamiast czerpać $\mathrm{z}$ natchnienia, $\mathrm{z}$ fantazji, z objawienia, zamiast się opierać na powadze czyjejkolwiek, czerpie poznanie jedynie tylko ze spostrzeżeń kontrolowanych i z rozumowań prawidłowych, wedle zasad, które formuje metodologia" 37 .

GŁÓWNE KATEGORIE NAUKOWO-BADAWCZE

Sady, czyli przekonania

W. Witwicki twierdzi, że w analizie stanów wewnętrznych, związanych z wiarą ludzi oświeconych, ,największą rolę grają przekonania, czyli sądy i zjawiska do sądów podobne" 38 . Przeciwstawiając się powszechnie przyjmowanemu od czasów Arystotelesa pojęciu ,sądu” jako połączeniu lub rozłączeniu pojęć, względnie pojęciu „sądu” jako wiary w obiektywny walor takiego połączenia, co wynikało z niedokładnego rozróżnienia „sądów” i „powiedzeń” (te ostatnie często bywają złożone z podmiotu i orzeczenia), idzie za Kartezjuszem, Hume'em, Brentaną, Twardowskim i pisze, że sąd, czyli przekonanie, to „to samo, co się inaczej nazywa przeświadczeniem o istnieniu czegoś, wiarą w istnienie czegoś, przyznawaniem czemuś rzeczywistości lub odmawianiu czemuś istnienia, fakt psychiczny, któremu przysługuje cecha prawdy lub fałszu. Na przykład: Jestem przekonany, że teraz jest dzień, albo sądzę, że nie istnieją wilkołaki" ${ }^{39}$. Na innym miejscu podaje krótsze określenie, a mianowicie, że „sądem, przekonaniem, przeświadczeniem, czyli wiarą w znaczeniu świeckim nazywamy fakt psychiczny uznawania rzeczywistości jakiegoś przedmiotu lub odmawiania mu rzeczywistości" ${ }^{40}$. Przedmiotem tak pojętego sądu jest to, cze-

35 Tenże, Sztuka a nauka, „Ateneum Polskie” 1 : 1908 nr 3 s. 279 - 287.

${ }^{36}$ Tenże, O stosunku nauki do sztuki, „Nauka Polska” 3 : 1920 s. 53 - 59.

37 Tenże, Psychologia, t. 1..., s. 13; por. tenże, Analiza psychologiczna objawów woli, Lwów 1904 , s. 17

${ }_{38}$ Tenże, Wiara oświeconych..., s. 24.

39 Tenże, Psychologia, t. 1 ..., s. 375; por. także: tenże, Podziat życia psychicznego. Uwaga, pamiéć, fantazja, „Wiadomości z Psychologii” 1947 z. 4 s. 2.

40 Tenże, Wiara oświeconych..., s. 24. 
mu w sądzie przyznaje się albo odmawia rzeczywistego istnienia ${ }^{41}$. Przedmiotem sądu może być przykładowo „rzecz lub osoba, zjawisko fizyczne, fakt psychiczny, stan rzeczy, cecha, stosunek, związek między faktami itd." 42

W. Witwicki rozróżnia: sądy twierdzące, których przedmioty istnieją i wówczas są to sądy prawdziwe, oraz sądy twierdzące, których przedmioty nie istnieją i wówczas są to sądy fałszywe; sądy przeczące, których przedmioty nie istnieją i wówczas są to sądy prawdziwe, oraz sądy przeczące, których przedmioty istnieją, a my odmawiamy im istnienia i wówczas mamy sądy mylne, czyli fałszywe ${ }^{43}$. Sądy o istnieniu przedmiotów w świecie realnym nazywa sądami realizującymi dlatego, że w nich uznajemy rzeczywistość otaczającego nas świata ${ }^{44}$. W sądach klasyfikujących wyrażamy przekonanie o przynależności danego przedmiotu do pewnej klasy przedmiotów na podstawie spostrzeżenia, że podobny czy podobne przedmioty już znamy ${ }^{45}$. Sądy wykluczające mamy wtedy, gdy np. bajki rozumiemy jako bajki, gdy słuchamy oczywistych kłamstw, gdy mamy do czynienia z obrazami ze snów itp., tzn. wykluczamy realne istnienie tych osób, przedmiotów czy zdarzeń. Jako przykład tego rodzaju sądów Autor podaje również:

Na każdym niemal grobie czytamy: „Tu spoczywa...”, chociaż nikt rozumny ani przez chwilę nie myśli naprawdę, żeby w jakimkolwiek grobie jakikolwiek człowiek spoczywał. Przecież zwłoki to na pewno nie czlowiek, a gnić to nie spoczywać. To wiedzą wszyscy nawet wtedy, gdy „wierzą” napisom na grobach. Podobne stany przekonania, które jak gdyby leżalo na wierzchu, a nie sięgało dna duszy, znajdzie zresztą łatwo każdy we własnym doświadczeniu. Mogą więc być przekonania powierzchowne i może ktoś swoje supozycje brać za przekonania ${ }^{46}$.

Tego rodzaju sądy nazywają się przedstawieniowymi, czyli wyobrażeniowymi, względnie supozycyjnymi - ich przedmiot nie istnieje, w przeciwieństwie do sądów przekonaniowych, których przedmioty realnie istnieją ${ }^{47}$. Uczyniwszy znamienne zastrzeżenia, a mianowicie, że „bardzo trudno nieraz dojść, czy ktoś - kogo słuchamy — wyraża swoje przekonania czy supozycje" 48 , Autor nie używa już terminu „sądy przekonaniowe”, ale posługuje się terminem „przekonania”, pisząc o przekonaniach szczerych i o przekonaniach nieszczerych. Pierwsze budzą się w nas same i tkwią nieodparcie w nas. Nie zachodzi potrzeba czynnego udziału w nich naszych władz, poza zdolnością czynnego skupienia uwagi, które w tym przypadku jest potrzebne. Jako przykład tego rodzaju przekonań Witwicki podaje przekonanie, że krowy mają cztery nogi,

${ }^{41}$ Tenże, Psychologia, t. 1..., s. 375.

${ }^{42}$ Tenże, Wiara oświeconych..., s. 24.

43 Tenże, Psychologia t. 1..., s. 376; tenże, Myślenie, „Wiadomości z Psychologii” 1947 z. $5 \mathrm{~s} .1$

44 Tamże, s. 227

45 Tamże, s. 227, 295.

46 Tamże, s. $334-335$.

47 Tamże, s. 195.

48 Tenże, Wiara oświeconych..., s. 42. 
pająki osiem i że Ameryka leży na zachodniej półkuli, bo je policzył, bądź że nie byłby w stanie wytłumaczyć wielu faktów związanych z Ameryką, z którymi się spotyka. Przekonania nieszczere to te przekonania, „które czynnie, umyślnie w sobie wywołujemy lub utrzymujemy, a one nie powstają w nas same i nie tkwią w nas nieodparcie" 49 .

\section{Supozycje}

Drugą kategorią naukowo-badawczą, którą prezentuje Witwicki, są tzw. supozycje. Na pytanie czym one są, odpowiada:

Stany wewnętrzne, które nazywamy supozycjami, przeżywamy, kiedy rozumiemy, co ktoś mówi o czymś lub pisze, chociaż nie podzielamy jego przekonań; kiedy gramy jakąś rolę albo oglądamy aktora podczas dobrej gry; kiedy rozumiemy treść obrazu, przejmujemy się wierszem, powieścią, poematem, ale nie wierzymy, żeby przedmiot tej poezji istniał naprawdę; kiedy rozpatrujemy motywy postanowienia, zanim się zdołamy zdecydować i pójść za którymś z nich; kiedy budujemy zamki na lodzie i pałace na księżycu, puszczając wodze fantazji, ale nie wierząc, żeby istniały naprawdę; kiedy bierzemy za dobrą monetę opowiadania poważnego człowieka, które same przez się się budzą zaufania. Wyrażamy supozycje w zdaniach niezależnych takich samych, jak wyrazy sądów, a oprócz tego, w zdaniach pobocznych warunkowych, pytajnych i w pewnych przedmiotowych, a więc zaczynających się od gdyby, jakoby, podobno, od czy i od że. [...] Żadna supozycja nie jest przekonaniem, każda jest tylko „przekonaniem na niby”, przekonaniem pozornym, cieniem przekonania, ponieważ brak jej istotnego dla przekonań momentu wiary (w znaczeniu świeckim). Żadna też nie jest samym tylko przedstawieniem, ponieważ przedstawienia te nie zawierają momentu twierdzenia lub przeczenia, a każda supozycja ma postać twierdzącą lub przeczącą, tylko bez wiary w swój przedmiot. Przeżycia estetyczne, teatr i literatura piękna są naturalnym polem supozycji, związanych z uczuciami — też często, choć niekoniecznie, pozornymi ${ }^{50}$.

Supozycją Witwicki nazywa również przypuszczenie ${ }^{51}$ i wątpienie ${ }^{52}$, którym brak oczywistości i pewności ${ }^{33}$, a także niekiedy przekonania nieszczere ${ }^{54}$, a więc takie, „które żywimy jedynie pod wpływem nakazu lub chęci własnej lub cudzej" 55 . Nakaz lub chęć jest więc pierwszym źródłem supozycji. Tego rodzaju przekonania właściwie nie są przekonaniami, tylko supozycjami, wytworami pewnej pozy, podobnie jak koń malowany nie jest koniem, tylko malowi$\mathrm{dłem}^{56}$. Człowiek - pisze Witwicki - może doskonale w siebie wmawiać, że kocha iksa, nie szanuje ypsylona, albo rozumie zeta, a w cichej głębi duszy wiedzieć, że nie istnieje ani jego efektowna miłość, ani prawdziwy szacunek, ani

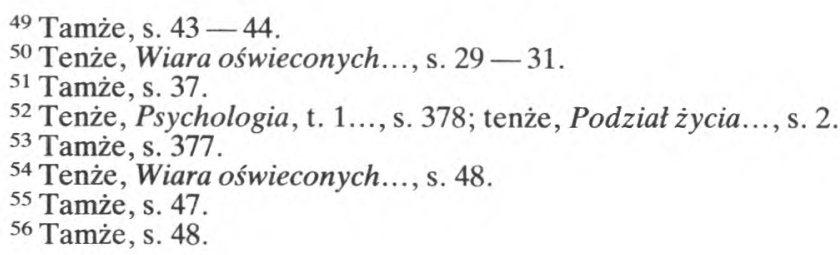


rozumienie ${ }^{57}$. Drugim źródłem supozycji może być wpływ innych ludzi i to tak mocny, że supozycje mogą przechodzić w przekonania, a nawet w pewność osobistą, co oczywiście nie znaczy, że im odpowiada obiektywna rzeczywistość. Przy przekonaniach mówimy: wiem, a przy supozycjach szczerych i nieszczerych: wierzę, że tak jest ${ }^{58}$.

Po przedstawieniu pojęcia i genezy supozycji Witwicki mówi o ich dwu zasadniczych cechach, a mianowicie o „sile” i ,żywości”. Ze znamieniem „siły” supozycji mamy do czynienia wtedy, gdy mówimy o relacji supozycji do sądu (przekonania) i do przedstawienia (wyobrażenia). Im supozycja bliższa jest sądu twierdzącego, tym jest mocniejsza, a im bliższa sądu przeczącego, tym jest słabsza ${ }^{59}$. Najtrafniej — zdaniem Witwickiego — można opisać to, co się dzieje w duszy ludzkiej, w związku z uznawaniem czegokolwiek, gdy zwróci się uwagę na następujący szereg możliwych faktów psychicznych. Na jednym końcu mamy czyste przedstawienie (wyobrażenie bez uwzględnienia rzeczywistości lub nierzeczywistości jakiegoś przedmiotu), a na drugim przekonanie, że jakiś przedmiot istnieje lub nie istnieje (sąd twierdzący lub przeczący), czyli pewność naturalną odpowiadającą oczywistości jakiegoś stanu, jak się to określa w języku teologicznym. Pomiędzy tymi dwiema końcowymi sytuacjami występuje szereg supozycji coraz bardziej mocnych, tzn. zbliżonych do przekonania, lub coraz słabszych, tzn. zbliżonych do czystego przedstawienia (wyobrażenia).

Jednak supozycja, której siła równa się zero, czyli jest pozbawiona wszelkiej siły, nie jest jednak tym samym, co przedstawienie. W czystym bowiem przedstawieniu (wyobrażeniu) nie bierze się pod uwagę tego, czy jakiś przedmiot istnieje i wówczas człowiek nie próbuje się do niego ustosunkować ani naprawdę ani na niby. W supozycji natomiast bierze się pod uwagę to, czy jakiś przedmiot istnieje czy nie i próbuje się na niby ustosunkować do niego twierdząco lub przecząco.

Supozycja daleka od przekonania twierdzącego nazywa się wątpieniem, a bliska temu twierdzeniu przypuszczeniem. Przypuszczenia i wątpienia są sądami subiektywnymi i dlatego przy małej sile godzą się z przekonaniami sprzecznymi nie tylko psychologicznie, ale także i logicznie. Przypuszczenia wydają się tym silniejsze, im mniejszy opór człowiek odczuwa przy próbach wydawania sądów twierdzących tej samej treści, wątpienia — odwrotnie: wydają się tym silniejsze, im człowiek czuje się bliższy zaprzeczeniu, a dalszy od stwierdzeń pewnego stanu rzeczy.

Supozycja przy pewnym nasileniu może przeskoczyć punkt graniczny i przejść w przekonanie. Jest to moment, w którym zjawia się pewność osobista, tzn. szczere przeświadczenie, wiara, że coś istnieje lub nie istnieje. Ta pew-

${ }^{57}$ Tenże, Psychologia, t. 1..., s. 376.

58 Tenże, Wiara oświeconych..., s. 48 - 49.

59 Tenże, Psychologia, t. 1..., s. 378. 
ność może mieć swoje stopnie - podobnie jak siła supozycji przypuszczających i wątpiących ${ }^{60}$. Sąd nazywa się pewnym, gdy nie można go zastąpić sądem o jakości przeciwnej. Tak silnie mogą tkwić w człowieku sądy zarówno prawdziwe jak i mylne, o mylności których człowiek nie wie. Gwarancją prawdy nie jest więc pewność osobista. Sąd niepewny nie narzuca się nieodparcie człowiekowi, który wie, że w tej chwili potrafiłby mieć przeciwne zdanie ${ }^{61}$. Istnieją również takie sądy, w których prawdziwość nie można wątpić i nazywają się sądami oczywistymi62. Poza sądami oczywistymi (zob. wyżej) wszystkie inne stany określa Witwicki supozycjami, które człowiek przeżywa w przypuszczeniach, wątpieniach, wahaniach, pragnieniach, rozważaniach, ewentualności, dowodzeniach ad absurdum, sztukach teatralnych, filmach itd. ${ }^{63}$

W sytuacjach przeżywania supozycji na tle źródła (jest to według Witwickiego trzecie źródło supozycji), które podaje jawnie sprzeczne sytuacje, a które budzi w człowieku strach, cześć, miłość, zaspokaja dawny nawyk, ludzie oprócz brania na siebie winy, że nie rozumieją i zasłaniania się tajemnicą, mogą jeszcze alegorycznie pojmować informacje sprzeczne pochodzące z czczonego źródła, gasić tendencje logiczne swoich sądów szczerych lub je czynnie tłumić albo wreszcie mimowoli ulec obezwładnieniu tych tendencji pod wpływem uczuć. Ludzi opada rodzaj paraliżu logicznego w tym zakresie; on im pozwala jakoś uważać za prawdę twierdzenia, które sami w głębi duszy uważają za nieprawdopodobne lub wewnętrznie sprzeczne. Zachodzi w nich pewne rozdwojenie. Ta lepsza wiedza, trafne dostrzeganie związków logicznych zapada w nich pod poziom świadomości i nie działa, a nad jej poziomem ludzie związani uczuciowo starają się utrzymać nieszczere przekonania, ale zgodne $\mathrm{z}$ ich tendencją uczuciową, z ową czcią czy obawą lub nawykiem. Mówią wtedy, że wierzą, a poświęcają przy tym swój rozum ${ }^{64}$. Jako przykład tego mechanizmu psychologicznego podaje głoszoną przez św. Pawła w Atenach doktrynę o zmartwychwstaniu (Dz 17, 32) i o. Chrystusie (1 Kor 1, 22 - 23): Tak więc, gdy Żydzi żqdajq znaków, a Grecy szukaja madrości, my głosimy Chrystusa ukrzyżowanego, który jest zgorszeniem dla Żydów, a głupstwem dla pogan. Witwicki przytacza również w tym samym celu wypowiedź Tertuliana: Powieszony zostat na krzyżu Syn Boga; nie wstydzimy się dlatego, że to wstyd. I umart Syn Boga; to calkiem godne wiary, bo to naiwne. I pochowany zmartwychwstat, to jest pewne, bo to jest niemożliwe ${ }^{65}$. To „poświęcenie rozumu” na rzecz wiary, zawarte w cytowanych wypowiedziach, i prawdy w nich podane uznano w wiekach średnich za prawdy „zostające ponad rozumem ludzkim,

60 Tenże, Wiara oświeconych ..., s. 32 - 38; tenże, Objaśnienia do księgi trzeciej: Plat on, Państwo t. 2, Warszawa 1958, s. 147.

61 Tenże, Psychologia, t. $1 \ldots$, s. 378.

62 Tamże, s. 377.

${ }^{63}$ Tamże, s. 335; tenże, Wiara oświeconych, s. 32.

64 Tenże, Wiara oświeconych..., s. 70 - 71 .

65 Tamże, s. 71. 
prawdy niepojęte, w które jednak nie tylko można, ale nawet trzeba wierzyć pod karą śmierci i pod grozą piekła"66. Postawienie ich ponad rozumem ma zdaniem Witwickiego - świadczyć, że ci, którzy przyjęli nadrzędny status podobnych twierdzeń, odczuwali sprzeczność między przyjmowaną. doktryną a postulatami racjonalności. Dlatego też nie mogli włączyć danej doktryny do zbioru racjonalnych twierdzeń; to „ponad”, a nie „pod” lub „obok” świadczy, że odczuwali dla określonych tez głęboką cześć.

Pogłębienie czci w tych wypadkach jest też psychologicznie zrozumiałe. Cześć jest najlepszym izolatorem przed niebezpiecznymi aktami czuwającego intelektu. Czlowiek instynktownie schyla głowę i przymyka oczy także i w tych wypadkach, gdy podświadomie wie i czuje doskonale z góry, co by miał zobaczyć, gdyby je miał przytomnie otwarte. Jeszcze gorliwiej zamyka wtedy oczy dru$\operatorname{gim}^{67}$.

\section{UWAGI KRYTYCZNE}

\section{Problem nauki i prawdy}

Próbując zająć własne stanowisko wobec przedstawionych wyżej poglądów W. Witwickiego, należy podkreślić, że jego podstawowe założenie naukowobadawcze (dotyczące roli nauki i sposobów dojścia do prawdy) można sprowadzić do syntetycznego ujęcia, określonego mianem naukowego empiryzmu. On bowiem stanowi główne założenia poglądów naszego autora. Otóż trzeba stwierdzić, że nie tylko empiria w sensie uznawanym przez Witwickiego jest źródłem poznania i nie tylko istnieje to, co człowiek poznaje jako oczywiste na zasadzie poznania spostrzeżeniowego i rozumu naukowego.

W podobnych ujęciach metanaukowych widać wyraz przedkrytycznej filozofii nauki. Absolutyzację poznania przyrodniczego łączono w niej z romantyczną wizją nauk szczegółowych. Późniejsze prace K. Poppera, M. Pelanyia, T. S. Kuhna doprowadziły do głębokich rewizji w tym ujęciu, które można by nazwać „metanauką ludzi oświeconych”. Było ono zdominowane przez zdroworozsądkowe przekonania, które nie znajdowały potwierdzeń w praktyce badawczej najbardziej rozwiniętych dyscyplin przyrodniczych ${ }^{68}$.

Takie poznanie wyczerpuje u Witwickiego poznawalne możliwości człowieka w odniesieniu do otaczającej go rzeczywistości. W przypadku jednak ro-

66 Tamże, s. 71 - 72: Heretycy zastuguja, żeby ich zgładzić ze świata [...] i stusznie się ich na śmierć wydaje [...] o wiele bardziej heretyków można zaraz, jak tylko się im herezji dowiedzie, nie tylko ze spoteczności wykluczyć, ale i sprawiedliwie zabijać ('To m as z z A k w in u, Summa teologiczna $\mathrm{II}^{\mathrm{a}} \mathrm{II}^{\mathrm{ae}} \mathrm{q} .11$ a. 3).

67 Tamże, s. 72.

68 R. Jones, Physics as Metaphor, New York 1982, s. 14; H. Prosch, Meaning, Chicago 1975, s. 182; W. H. New to - S mith, The Rationality of Science, Routledge and Kegan Paul 1981, s. 184; T. K u h n, Theory Change as Structure Change, „Erkenntnis” 10:1976 s. 190. 
zumowania heurystycznego, jako drogi do poznania rzeczywistości, chociaż nie opiera się ono na danych oczywistych nieodparcie budzących u człowieka odpowiednie przekonania - jak twierdzi autor - to przecież stanowi ono niewątpliwie źródło poznania. Korzystają z niego nie tylko ci badacze, których pojęcie i drogi ich naukowego poznania ogranicza Witwicki. Autor nie uznaje poznawczej roli rozumu w znaczeniu metafizycznym, uważając, zgodnie ze swoim zawężonym pojęciem sposobów poznania, że nie stanowi on narzędzia poznania i nie uznaje również wielowymiarowej rzeczywistości69.

Nie ma takiego poznania, które by w jednakowy sposób odnosiło się do wszystkich dziedzin rzeczywistości, np. do ujęcia reakcji chemicznej, aparatury maszynowej, wzrostu rośliny, decyzji moralnej, filozoficznego ujęcia istoty itp. Nastawieniu poznawczemu, które jednego rodzaju aktom ujmuje poszczególne dziedziny bytu, wymyka się to, co jest właściwe dla każdego z nich osobno $^{70}$.

Potwierdzeniem tego jest między innymi jego (W. Witwickiego) pogląd na nieśmiertelność duszy ludzkiej, którą uważa autor za przedmiot wiary. Stąd usiłuje wykazać, że istnieje sprzeczność między twierdzeniami z zakresu wierzeń religijnych a twierdzeniami naukowymi. W dziedzinie przekonań religijnych widzi wewnętrzne sprzeczności, dlatego, że język Biblii tłumaczy on na język jednoznaczny i np. w danych Pisma Świętego nie uwzględnia tego, że nie wszystkie dane Biblii są opisem faktów, ale zawierają $\mathrm{m}$. in. elementy dydaktyczne.

\section{Zagadnienie przekonań (sądów)}

Witwicki ogranicza sądy realne o rzeczywistości do otaczającego nas świata materialnego. Sądy realne są rzeczowe, obiektywne, a sądy nierzeczowe podmiotowe, subiektywne. Oprócz sądów realnych przyjmuje tzw. supozycje. W konkluzji całokształt zagadnienia sprowadził do alternatywy: istnieją przekonania (sądy realne) albo supozycje. Nie ma miejsca na „coś trzeciego”. Sprawa staje się jeszcze mniej jasna dlatego, że pojęcie przekonania nieszczerego utożsamia niekiedy z supozycją, co może mylić czytelnika. Według autora przekonanie zawiera element rzeczywistości obiektywnie istniejącej, a określenie „nieszczere” utożsamia z supozycją, której przedmiot nie ma tego elementu rzeczywistości istniejącej obiektywnie ${ }^{71}$. Za nieszczere uważa również

${ }^{69}$ A. Maryniarczyk, rec. [z:] Bèla We issmahr, Ontologie. Grundkurs Philosophie, Band 3, Stuttgart - Berlin - Köln - Mainz 1985, s. 182, [w:] „Studia Philosophiae Christianae” $25: 1989$ nr 2 s. $232-237$.

${ }^{70}$ M. J a w or s ki, Religijne poznanie Boga (Próba charakterystyki na tle pogladów R. Guardiniego), „Zeszyty Naukowe Katolickiego Uniwersytetu Lubelskiego” 4 : 1961 nr 3 (15) s. 39.

${ }_{11}$ W. Wit wi cki, Wiara oświeconych..., s. $44-45,48$. 
te przekonania, które człowiek czynnie i umyślnie w sobie wywołuje lub podtrzymuje, a one nie powstają w człowieku same i nie tkwią w nim nieodpar$\mathrm{cie}^{72}$. Jest to specyficzne rozumienie przekonań nieszczerych.

W. Witwicki twierdzi, że sądy oczywiste (przekonania) umożliwiają nam poznawanie istniejącej rzeczywistości. Wszystkie inne sądy nie są sądami oczywistymi i nie mówią o rzeczywistości istniejącej obiektywnie, lecz są subiektywnym tworem o nie istniejącej obiektywnie rzeczywistości. Z takiego ujęcia zdaje się wynikać, że według Autora, jeśli coś nie jest oczywiste, tzn. poznane na zasadzie spostrzeżeń i nieodpartego wnioskowania - po prostu nie istnieje. Takie stwierdzenie ,jest wynikiem dziewiętnastowiecznych zapatrywań scjentystycznych. Wielu uczonych przyjmowało wiarę w nieograniczone możliwości rozumu ludzkiego oraz doświadczenia empiryczno-zmysłowego. [...] Taka postawa scjentyzmu dogmatycznie kwestionowała możliwość pogodzenia wiary i nauki. [...] Bezwzględne zaufanie do nauki cechowało także Witwickiego"73. Taki ideał nauki został zakwestionowany. Stało się to na skutek zmian „postawy uczonych, którzy zerwali z dogmatyzmem scjentystycznym. W nauce pewność nie jest już uznawana za obiektywne kryterium weryfikowalności zdań. Miejsce to zajmuje prawdopodobieństwo jako sprawdzian słuszności teorii naukowych. [...] Tak więc i poglądy scjentystyczne zakładające antagonizm między wiarą i nauką nie są dzisiaj uznawane. Szukanie przez Witwickiego rozwiązania problemu wiara a nauka w supozycyjnym charakterze aktów wiary traci dzisiaj swą zasadność"74.

W analizie krytycznej powyższych danych nieprzekonywającą wydaje się wypowiedź w sprawie człowieka, który wierzy w życie pozagrobowe, a nie chce na ten temat rozmawiać ${ }^{75}$. Nasz Autor uważa przekonanie badanego w tej dziedzinie za nieszczere, które mimo swej własnej, głębszej wiedzy chce zachować i dlatego nie podejmuje na ten temat dyskusji. Trzeba jednak postawić jasno następujące pytanie: Czy takie uzasadnienie jest wystarczające i słuszne? Przecież ten człowiek może po prostu nie umieć podać racji swego przekonania nawet szczerego. W sytuacjach dylematów światopoglądowych nieomal każdy człowiek w swym życiu spotyka się ze sprawą — nie tylko w dziedzinie religijnej — co do której jest przekonany, a nie potrafi ani jaśniej jej przedstawić, ani swego przekonania głębiej czy naukowo uzasadnić. Bywa i tak, że ktoś jest przekonany, a nie chce o tym mówić, albo może bać się dyskusji, bo nie czuje się mocny w argumentacji. Ma jednak racje, które dla niego są wystarczającym uzasadnieniem jego przekonań, a do rozmówcy o przeciwnych przekonaniach nie ma zaufania.

${ }^{72}$ Tamże, s. 44, 47.

${ }^{73} \mathrm{Z}$. K r oplew s ki, Przekonaniowy aspekt aktów wiary religijnej. Studium krytyczne W. Witwickiego teorii przekonañ, [w:] Radość z nadziei. W 25-lecie postugi biskupiej ordynariusza koszalińsko-kotobrzeskiego, Koszalin 1985, s. 205 - 206.

74 Tamże, s. 206.

${ }^{75}$ W. Wit wicki, Wiara oświeconych..., s. 46-47. 
Trzeba jeszcze zauważyć, że rzeczywiście w przekonaniach występuje element poznania i wówczas mówimy: „wiem”, natomiast w postawie religijnej element „wiem” jest wtórnym wobec przekonania płynącego z wiary. Wiem, że źródłem przekonań i wiedzy jest nie tylko poznanie empiryczno-zmysłowe i rozumowe (nie w znaczeniu filozoficznym), lecz również rozumowe w znaczeniu filozoficznym, a zwłaszcza metafizycznym, a także Objawienie Boże. W tym ostatnim wypadku należy uwzględnić jego język obrazowy, a także formy antropomorficzne i literackie. W sumie - wierzący powinien wiedzieć, dlaczego wierzy i to powinno stać się przyczyną jego przekonań religijnych. Te określone przekonania religijne, które nie zasadzają się na oczywistości - nazwane przez Witwickiego przekonaniami nieszczerymi — są według niego niesłuszne. Człowiek jednak może mieć racje prawdopodobnościowe i dlatego przyjmuje dane wiary, mając pewność moralną.

\section{Specyfika supozycji}

Odnośnie do sytuacji przeżywania supozycji na tle (wspomnianego trzeciego) źródła, które·dotyczy jawnie sprzecznych sytuacji, to człowiek wierzący niekoniecznie takie sprzeczne sytuacje widzi lub dostrzega w podobnych informacjach o sprzeczności. Może ich przecież nie dostrzegać. Gdy zwróci mu się na to uwagę, gotów jest przypisać winę sobie. Może bowiem być i tak, że człowiek zdaje sobie sprawę, iż nie potrafi dostrzec wielowymiarowości czy innych aspektów rzeczywistości. Nie wyraża zgody na rzekomą sprzeczność. Można więc psychologicznie rozumieć również w ten sposób, że zachodzi jeszcze inny wymiar rzeczywistości. A więc może być inna możliwość, której Witwicki nie dostrzega. Człowiek wierzący zdaje sobie bowiem sprawę z bogactwa rzeczywistości i różnych sposobów jej poznawania. Nie można do poznawania rzeczywistości zastosować tylko i wyłącznie metody nauk empirycznych, ale nawet już w świecie empirycznym spotykamy się z różnymi teoriami ujmowania rzeczywistości. W fizyce, np. w mechanice kwantowej, współistnienie modelu falowego i korpuskularnego nie jest oznaką sprzeczności, ale komplementarności ${ }^{76}$. Rozwój nauki przyniósł doświadczenie granic metody nauk empirycznych. Zdano sobie sprawę z tego, że „nauki empiryczne są tylko jedną z postaci racjonalności i poza ich granicami istnieje też inny obszar, w którym mieści się też doświadczenie religijne" 77 .

Przyjmując jeden prosty mechanizm usprawiedliwiający generowanie wierzeń, których nie można czysto racjonalnie uzasadnić, Witwicki wśród uzna-

${ }^{76}$ J. Ży cińs k i, Teizm i filozofia analityczna, t. 1, Kraków 1985, s. 32; por. J. G. B a r b ou r, Mity, modele, paradygmaty..., s. $92-101$; H. Fries, Wiara zakwestionowana, Warszawa 1975, s. 39-40; M. A. K r ą p i e c, Konfesyjność uczelni $i$ wolność nauki, „Zeszyty Naukowe Katolickiego Uniwersytetu Lubelskiego" $1: 1958 \mathrm{nr} 1 \mathrm{~s} .17-19$.

${ }_{77}$ Filozofować w kontakcie nauki, red. M. Helle r, A. Michali k, J. Życiński, Kraków 1987, s. 34; por. J. Ż y cińs ki, W kręgu nauki i wiary, Kalwaria 1989, s. 32. 
nych zasad metanaukowych wprowadza założenia przyjęte aksjomatycznie. Pomija całkowicie fakt, że również w sytuacjach przesunięcia paradygmatu w naukach szczegółowych przemiany w nauce dokonują się dzięki przyjęciu nowych zasad pozbawionych hic et nunc racjonalnego uzasadnienia. Z dalszym rozwojem nauki zasady te mogą zostać częściowo zracjonalizowane. Brak podobnej racjonalizacji nie stanowi jednak bynajmniej specyfiki wierzeń religijnych. Większość przełomowych teorii przyrodniczych krytykowano początkowo $\mathrm{z}$ racji domniemanego braku racjonalności. W tym kontekście wysoce wątpliwa wydaje się interpretacja Witwickiego, przypisująca pogłębionej czci funkcje epistemologiczne ${ }^{78}$.

\section{Nauka a wiara}

Oceniając założenia epistemologiczne leżące u podstaw krytyki religii przez W. Witwickiego, trzeba wziąć pod uwagę przede wszystkim jego koncepcję empiryzmu poznawczego. Wychodząc z założenia, że tylko to jest naukowe i rzeczywiste, co poznaje się na zasadzie spostrzeżeń i nieodpartego wnioskowania, doszedł on do zawężenia zarówno dziedzin rzeczywistości uznawanej za obiektywną, jak i metod jej poznania. jest to koncepcja, której dzisiaj już nie można podtrzymywać ${ }^{79}$. Wynikiem takiego podejścia do interesującego nas zagadnienia było uznanie za realną jedynie rzeczywistości materialnej i wykluczenie takich sposobów poznania, jakie są możliwe przy pomocy rozumu filozoficznego, zwłaszcza metafizycznego oraz dzięki uznaniu nadprzyrodzonego Objawienia. Podobne ujęcie doprowadziło go do jednowymiarowego widzenia, poznania, uznania i wyrażania rzeczywistości tak samego człowieka, jak i otaczającego go świata. W takiej perspektywie nie było miejsca ani dla religii, ani dla wiary. Jednakowoż codzienne spostrzeżenia i doświadczenia mówiły coś innego, wręcz odwrotnego. Nic więc dziwnego, że badawcza pasja naukowca „zmusiła” go do podjęcia próby wyjaśnienia faktu wiary, z którym się spotykał nie tylko u ludzi niewykształconych, ale także u osób „oświeconych”, tzn. mających przynajmniej wykształcenie średnie.

Pomijając poznanie metafizyczne doszedł $\mathrm{W}$. Witwicki do wniosku, że to wszystko, co nie jest jego zdaniem oczywiste, nie stanowi przekonań człowieka, ale jest przedmiotem supozycji, czyli sądów nieszczerych. A jednak trzeba zauważyć, że przedmiot wiary nie utożsamia się z rzeczywistością badaną empirycznie. Poznanie filozoficzno-metafizyczne i poznanie przez wiarę, prowa-

${ }^{78}$ C. R. Kordig, The Hustification of Scientific Change, Dordrecht 1971, rozdz. 2.

79 A. Gould ne r, The Coming Crisis of Western Sociology, New York 1970, s. 103; R. S u ken ick, „Upward and Juanward: The Possible Dream”, [w:] Seeing Castaneda: Reaction to the „Don Juan” Writings of Carlos Castaneda, New York 1976, s. 113; J. Z y cińs k i, Wybrane zagadnienia z filozofii nauki (część I), [w:] Z zagadnień filozofii przyrodoznawstwa i filozofii przyrody, red. M. Lubański, S. W. Slaga, t. 10, Warszawa 1988, s. 49, 65. 
dząc do Boga, rodzi przekonanie o prawdziwości Boga. Przyjmując poglądy filozoficzne K. Twardowskiego, podobnie jak on, W. Witwicki nie uwzględnia roli pojęcia analogii w poznaniu i wyrażeniu treści religijnych. $\mathrm{Z}$ tego powodu trudno mu było interpretować adekwatnie wiarę badanych i sprawiedliwie ją oceniać.

Wiele wypowiedzi W. Witwickiego wskazuje na to, że nie tylko nie doceniał roli rozumu w akcie wiary, ale właściwie zupełnie go wykluczał. Wierzący nie są racjonalistami ani deistami. Uznają jednakowoż rolę, jaką rozum odgrywa w akcie wiary. Podobnie Kościół traktuje racjonalne ujęcie jako jeden ze składników aktu wiary. Rozum ukazuje jednak innego rodzaju doświadczenie rzeczywistości niż to, o którym mówi Władysław Witwicki. Dziedzinę jego aktywności stanowią m. in. tezy opatrywane mianem: praeambula fidei. Podprowadza on do przyjęcia tego, co nie jest oczywiste. Analiza wiary pokazuje, że w procesie poznania nie ma tej ścisłości, co w naukach matematyczno-przyrodniczych. Niemniej zachodzi proces poznania, który pozwala budować wierzącym swe poglądy na sądach racjonalnie uzasadnionych ${ }^{80}$. Koncepcja Witwickiego może funkcjonować w odniesieniu do poznania świata rzeczy, a nie świata religii. Nie zna i nie uwzględnia doświadczenia religijnego.

Trzeba jednak przyznać rację Witwickiemu, gdy twierdzi, że poznanie przez wiarę jest czymś różnym od poznania czysto rozumowego; jednakże usiłowanie, by pozbawić wiarę elementu racjonalnego, jest nie do przyjęcia. To, co autor rozumie przez „sacrificium intellectus”, gaszenie tendencji logicznych, może odnosić się tylko do sądów empirycznych i tzw. ,rozumu naukowego" oraz instrumentalnego, odczytującego to i tylko to, co jest w wymiarze doświadczenia zmysłowego i zmierzającego do utylitarystycznego wykorzystania tegoż doświadczenia. Jest rzeczą wiadomą, że poznanie w wierze ma charakter personalny.

Rola woli, której udział w akcie wiary Witwicki tak mocno podkreśla, wynika z faktu, że w wierze nie ma takiej oczywistości, jaka skłania rozum do przyjęcia prawd $w$ dziedzinie świeckiej. Wierzący przyjmują działanie woli w akcie wiary; przekonanie, pochodzące $\mathrm{z}$ wiary nie jest przekonaniem niezależnym od woli. Wynika ono z innych sądów racjonalnie uzasadnionych, a rola woli nie sprowadza się tylko do rozkazu dla rozkazu, by zaakceptować daną rzeczywistość. Przyjęta w Wierze oświeconych interpretacja zarówno tekstów św. Tomasza, jak i relacji wola — poznanie, jest nie do przyjęcia. Autor pracy zbyt jednostronnie podkreśla udział woli w akcie wiary, nie docecniając roli rozumu $^{81}$.

${ }^{80}$ J. P a st uszk a, Psychologiczne źródta niewiary, Lublin 1946, s. 8-12; W. M a r c is zews k i, Wiara a koszty myślenia, „Tygodnik Powszechny” $14: 1960 \mathrm{nr} 19$ (589) s. 3. s. 170 .

${ }_{81}$ Między logika a wiarą. Z Józefem M. Bocheñskim rozmawia Jan Parys, Montricher 1988, 
Podobnie przedstawia się sprawa z wpływem autorytetu i uczuciem czci ${ }^{82}$. Jedno i drugie ma podstawę racjonalną (nie usuwa roli rozumu ludzkiego) ${ }^{83}$. Nie ma wprawdzie oczywistości, jak w naukach ścisłych, ale jest inny moment, skłaniający wierzącego do przyjęcia ich wpływu. Jest nim wiarygodność kompetentnych świadków. Jest to sprawa znana i akceptowana również w wielu innych dziedzinach wiedzy.

Istota problemu, który W. Witwicki usiłuje rozwiązać, sprowadza się do podstawowego pytania: czy wiara polega na przekonaniach czy też na tzw. supozycjach? Jak wynika $z$ dotychczasowych wypowiedzi, sprawa przedstawia się w zasadzie bardzo jasno. Autor Wiary oświeconych stoi na stanowisku, że wiara u człowieka polega wyłącznie i jedynie na supozycjach. $\mathrm{Z}$ takim rozwiązaniem problemu wierzący nie mogą się zgodzić ${ }^{84}$. Niesłuszna jest opinia, że przepisy wyznaniowe nie wymagają od wierzących szczerych i autentycznych przekonań w dziedzinie wiary. Taka interpretacja orzeczeń Kościoła jest po prostu fałszywa. Chociaż pewne prawdy nie są oczywiste, to Kościół domaga się jednak przekonań. Przekonania te nie wynikają z oczywistości poznania tak, jak je rozumie Witwicki, ale wynikają z poznania w szerszym ujęciu tego zagadnienia, opartego np. na zasadzie racjonalnego uzasadnienia czy heurystycznego wniosku. Ma się wówczas do czynienia z autentycznymi sądami szczerymi, odnoszącymi się do realnie istniejącego ,przedmiotu wiary”. Podobnie przedstawia się sprawa z uzasadnionym przyjęciem prawdy, pochodzącej od kompetentnego autorytetu. W wierze istnieją przekonania, do których dochodzi się nie na zasadzie dedukcyjnych inferencji logicznych, lecz na drogach, które prowadzą do zdobycia pewności moralnej. Bóg jako najwyższa wartość, zaufanie okazywane $\mathrm{Mu}$, będące wynikiem poznania międzyosobowego, nie jest czymś nieracjonalnym, a tym bardziej nierealnym.

Chcąc rozwiązać problem: wiara - nauka, bez dowartościowania roli przekonań w sferze religijnej, W. Witwicki uciekł się do pojęcia supozycji. Starał się przy jego pomocy zinterpretować tak wiarę w rozumieniu wyznaniowym, jak i wiarę osób ankietowanych. W analizie orzeczeń Kościoła i wypowiedzi teologów ukazuje swoje stanowisko, a nie zawartą w nich prawdę. Jeżeli chodzi o interpretację wiary osób badanych, to nasuwa się pytanie, czy trudności, jakie mieli oni w swej wierze, można rozwiązać na drodze supozycji? czyli ,przekonaniu na niby, na przekonaniu pozornym bez wiary w swój przedmiot" 85 .

${ }^{82} \mathrm{H}$. Grzy mała-Moszczyńska, Eksperyment psychologiczny Władysława Witwickiego $w$ badaniach nad wiarq religijna. W setnq rocznicę urodzin (1878-1948), „Studia Religiologica” 1980 z. 5 s. $127-128$.

83 J. P a st uszk a, Struktura świadomości religijnej. Próba nowej interpretacji, [w:] Pastori et Magistro, Lublin 1966, s. 320 - 324; por. J. M. B oc h én sk i OP, Logika a filozofia religii, „W drodze" $1988 \mathrm{nr} 2(174)$ s. 29 - 30; por. Tajemnica - to nie znaczy betkot. Z ojcem prof. Józefem M. Bocheńskim OP rozmawia ks. Dariusz Galbler, „W drodze” $1989 \mathrm{nr} 4$ (188) s. 88 - 89.

${ }^{84} \mathrm{~W}$. Ma rciszew ski, Podstawy logicznej teorii przekonań, Warszawa 1972, s. 160.

85 W. Witwicki, Wiara oświeconych..., s. 30 - 31; por. tenże, Psychologia , t. I..., s. 335; R. J a d c zak, Teoria ,supozycji” w ujęciu Wtadystawa Witwickiego, ,Acta Universitatis Nicolai Co- 
W. Witwicki określa mianem supozycji wszystko, czego nie zaliczył do sądów oczywistych. Wiedząc, czym jest supozycja w takim ujęciu, wierzący nie może się zgodzić z taką interpretacją jego wiary. Czy nie słuszniejszym byłoby rozróżnienie pomiędzy przekonaniami racjonalnie uzasadnionymi choć nie oczywistymi, na które może, czy nawet powinien zgodzić się wierzący? Rozwiązanie proponowane przez Witwickiego jest konsekwencją przyjętych przez Niego założeń i metody badań zjawiska wiary. Czy nie byłoby rzeczą trafniejszą rozwiązanie ewentualnych konfliktów, które widzi W. Witwicki, pomiędzy przekonaniami świeckimi a przekonaniami w dziedzinie wiary na drodze zasygnalizowanej przez nas sugestii o uzasadnionych racjonalnie przekonaniach religijnych? Możliwość taka wydaje się realna, gdyż między skrajnymi interpretacjami, które wchodzą w konflikt, można z zasady znaleźć stanowiska pośrednie, wolne od sprzeczności czy paradoksu. Tym bardziej wydaje się to słuszne, że w dziedzinie wiary trzeba zwrócić uwagę na fakt istnienia tajemnic. Tajemnice wiary nie są czymś sprzecznym i absurdalnym. Chociaż nie mieszczą się w tym samym porządku poznania i rzeczywistości, które przyjmuje Witwicki. Już było wspomniane o tym, że cała rzeczywistość jest wielowymiarowa i przy takim ujęciu nie można mówić o sprzeczności wiary i nauki, gdyż obydwie dziedziny mają różne poziomy i płaszczyzny ${ }^{86}$. Stąd nie wchodzi w grę ich ujęcie jednowymiarowe i analizowanie ich z jednego punktu widzenia - pod jednym i tym samym względem. Tajemnica wiary to nie jest sprzeczność, ale to rzeczywistość, wychodząca poza naturalne granice poznania, zwłaszcza w ujęciu Witwickiego. Coś z punktu widzenia semantycznego może być nawet sprzeczne, ale trzeba uznać, że problemy nie rozgrywają się na tym samym terenie, że nie są to dziedziny, które stoją sobie naprzeciw, ale raczej „linie”, które się nie przecinają, gdyż wyrażają prawdę w innych porządkach. Innego rodzaju jest doświadczenie religijne, a innego doświadczenie rzeczywistości podpadających pod poznanie zmysłowe. Nie ma tutaj naruszania psychologicznej zasady sprzeczności, gdyż ,uznawanie za prawdę” czegoś w dziedzinie wiary nie wynika z przekonań naturalnych, oczywistych w znaczeniu W. Witwickiego, ale wynika z określonych przekonań i sądów różnych od nich, zdobytych na innej drodze poznania. Gdyby tak nie było, wierzący przeżywaliby konflikt pomiędzy przekonaniami w dziedzinie wiary i w dziedzinie nauki. Wierzący może mieć trudności, ponieważ np. zmysły przy poznaniu spontanicznym mogą mówić coś innego, niż to, do czego można dojść przy głębszym poznaniu. Wnioski formułowane na podstawie danych zmysłowych możemy oczywiście sprawdzić, zaś wniosków wyprowadzonych w refleksji teoretycznej nie możemy jednak

pernici - Filozofia IV: Nauki humanistyczno-społeczne" 1979 z. 103 s. 40; A. La t ała, Teoria wiary religijnej Wtadystawa Witwickiego, „Studia Religiologica” 1980 z. 5 s. $138-139$.

${ }_{86}$ E. Ni z zn ańs ki, Logika przekonań a wiara oświeconych, ,Studia Philosophica Christianae” 21:1985 nr 1 s. 158; J. Ma k s el on, Relacje między psychlogia a religia, „Analecta Cracoviensia" $20: 1988$ s. $48-49$. 
bezwzględnie odrzucić, zwłaszcza gdy przemawiają za tym racjonalnie uzasadnione przesłanki.

Trzeba w tym miejscu wspomnieć jeszcze o języku przyjętym przez W. Witwickiego. Język ten nie jest w stanie oddać treści religijnych, gdyż jak wykazała nasza analiza, jest to język jednowymiarowy, jednoznaczny w swym odniesieniu do konkretnych obiektów empirycznych. Tymczasem język religijny, a zwłaszcza język Biblii, nie jest językiem nauk ścisłych. Jest on jakby polifoniczny, niesie wiele znaczeń i nie można go zredukować do płaszczyzny jednoznacznej, jak to zrobił W. Witwicki ze względu na wymogi tej metody naukowej, którą zastosował w swoich pracach. W zaistniałej sytuacji nie mógł on wyrazić ani zinterpretować treści religijnych, którymi się zajmował. Symboliczny język religii ma swoje bogactwo i swoją logikę, niezrozumiałą dla empiryzmu. Autor operuje językiem i kategoriami, które są ważne dla świata scjentystycznego. Badania wskazują na to, że nie da się poznania religijnego i języka religijnego zredukować do języka filozofii, przyjętej przez W. Witwickiego. Jako przykład można podać jego wywody na temat grzechu pierworodnego i dzieła Odkupienia. Te ważne prawdy wiary zostały we wprowadzonej perspektywie spłycone i zredukowane tylko do ludzkich wymiarów bez uwzględnienia zasad analogii.

\section{$* * *$}

Podsumowując krótko całokształt poruszanej problematyki, należy stwierdzić, że W. Witwicki doszedł do takich wyników dlatego, że opierał się na zawężonym pojęciu rzeczywistości ${ }^{87}$, redukując również sposoby jej poznawania, co uwidoczniło się $\mathrm{m}$. in. w pominięciu poznawczej roli (mediacji) filozofii. Przy takim podejściu do zagadnienia stosunku wiary i nauki te wyniki nie mają wartości bezwzględnie ważnych i trwałych osiągnięć naukowych. Wiara w rozumieniu konfesyjnym nie da się uzgodnić z jego interpretacją, przyjmującą teorię supozycji, jeśli w tej ostatniej pomija się asertywność przekonań religijnych opartą na odniesieniu wypowiedzi religijnych do ich desygnatów wykraczających zarówno poza dziedzinę języka, jak i zakres aktów psychicznych. Przyjęte przez W. Witwickiego założenia i metoda nie były w stanie rozwiązać postawionego problemu, gdyż rzeczywistość, którą się zajął, jest o wiele bogatsza i dlatego nie mogła zmieścić się w narzuconych jej arbitralnie ramach.

$\mathrm{W}$ dalszych badaniach tego rodzaju należałoby zrezygnować $\mathrm{z}$ apriorycznych założeń, które przyjął Autor. Nie należałoby także podtrzymywać nieuzasadnionych generalizacji, w których ocenia się rzeczywistość wiary, rozciągać na wszystkich wierzących, podobnie jak nie można formułować ogólnych

87 The Holographic Paradigm and Other Paradoxes, red. K. Wil be r, Boston 1982, s. 5; por. J. Ży cińs ki, Wybrane zagadnienia z filozofii nauki (część I)..., s. 104-108. 
wniosków na podstawie zależności odnoszących się do relatywnie niewielkiej grupy osób badanych. Trzeba byłoby zrezygnować z „parafrazy” świeckiej tekstu biblijnego, ponieważ nie tylko nie jest on potrzebny w tego rodzaju badaniach, ale wprowadza w błąd i spłyca całą problematykę.

Epistemologiczne i metodologiczne błędy zawarte w propozycjach Witwickiego można wyjaśnić przez uwzględnienie filozoficznego podłoża dominującego w epoce ich powstawania. W atrakcyjnych dla umysłów tamtej epoki przeciwstawieniach pozytywizmu usiłowano łączyć wspólnie teologię, metafizykę i poezję, kwestionując ich wartość poznawczą. Pozytywistyczny model nauki ukazał szybko zawarte w nim uproszczenia i arbitralności. W opracowaniach współczesnej epistemologii dotyczącej wielowymiarowej logiki wiary, niektóre z tez Witwickiego pojawiają się jako klasyczne przykłady zniekształcających ujęć istoty wierzeń religijnych ${ }^{88}$.

Uwagi i krytyczne zastrzeżenia wyrażone w niniejszym artykule nie przekreślają całkowicie wartości przedsięwzięcia W. Witwickiego na terenie nauki polskiej. Niektóre z rozróżnień i sugestii proponowanych przez autora Wiary oświeconych okazaly się niewątpliwie wartościowe heurystycznie. Ambitne założenia przyjęte w jego programie badawczym nie mogą jednak usprawiedliwiać ani uproszczeń metody, ani dowolności formułowanych wniosków.

Takie ujęcie zawęża drogi poznania rzeczywistości, gdyż nie przyjmuje innych sposobów poznania. Skutkiem tego aprioryczne założenia teoriopoznawcze podniesione zostają do rangi kryterium ontologicznego. Jego arbitralna akceptacja sprawia, iż pewne tezy religijne uznawane są za irracjonalne, zaś ich desygnaty za nierealne (nierzeczywiste) twory wyobrażeń osób wierzących.

\section{WŁADYSŁAW WITWICKI'S THEORY OF RELATIONSHIP BETWEEN SCIENCE AND FAITH}

\section{Sum mary}

The paper describes intellectual heritage of W. Witwicki and analyses his major works dealing with the relationship between science and religion. The author points out how the methodology of positivism that prevailed in the 1930's influenced Witwicki's critique of religion. This critique is assessed in this paper from the standpoint of the contemporary philosophy of sciense. Both unlimited trust in epiricist data and uncritical belief in rationality of science are called into question.

${ }^{88}$ I. G. B a rbour, Mity, modele, paradygmaty.., s. 49-50, $120-139,180-191$; por. J. Życiński, Posłowie, [w:] tamże, s. 235-261. 